\title{
The Indonesian EFL Teachers' TPACK Development in the Online Community of Practice
}

\author{
Agustina Tyarakanita ${ }^{1}$, Joko Nurkamto ${ }^{2}$, Nur Arifah Drajati ${ }^{3}$ \\ Universitas Sebelas Maret, Indonesia ${ }^{1,2,3}$ \\ agustinatyarakanita@student.uns.ac.id ${ }^{*}$
}

ARTICLE INFO
Article history:
Received
January 12th, 2021
Revised
July $21^{\text {st }}, 2021$
Accepted
September $11^{\text {th }}, 2021$

\begin{abstract}
This study sought to investigate teachers' TPACK level development after participating in a WhatsApp-based online community of practice (OCP) in Indonesia. This study addresses the issue of the teachers who are mandated to integrate technology in teaching. However, with a range of contexts, it is known that teachers lack confidence and competence in integrating technology. Therefore, a program for teachers that emphasizes theoretical and practice is one of the best solutions for improving their TPACK. A case study was adopted in this research. This study explored the practice process that took place in the OCP utilizing the notion of the community of practice (CoP) by Wenger (1998) and TPACK level by Niess (2015) to know the teachers' TPACK level development. The findings suggest that the TPACK level development was still not fully achieved by the teachers. This study recommends that the committee who designed the OCP carefully find the best way to make the teachers experience meaningful learning and achieve significant development on their TPACK.
\end{abstract}

Keywords: English as a foreign language; online community of practice (OCP); teachers' learning; TPACK; TPACK level development.

\footnotetext{
How to cite

Tyarakanita, A., Nurkamto, J., \& Drajati, N. (2021).The Indonesian EFL Teachers' TPACK Development in the Online Community of Practice. Pedagogy: Journal of English Language Teaching, 9(2). 121-134
}

DOI: 10.32332/joelt.v9i2.3229

Journal Homepage https://e-journal.metrouniv.ac.id/index.php/pedagogy

This is an open-access article under the CC BY SA license https://creativecommons.org/licenses/by-sa/4.0/

\section{INTRODUCTION}

To boost the learners' capacity, in learning and teaching. The digital teachers must gain knowledge and skill, revolution has already changed schools' 
education and learning system (Caena \& Redecker, 2019). Therefore, the need for teachers to acquire technological, pedagogical, and content knowledge (TPACK) is such a mainstream transformation in the educational system. TPACK develops the understanding that interconnects the technology to curriculum content and specific pedagogical approaches and helps teachers adjust those three components to produce effective discipline-based teaching with technology (Koehler et al., 2014). Moreover, TPACK is a frame of thinking that teachers depend on when designing and implementing curriculum and instruction while guiding learners for thinking and learning with digital technology in specific content areas (Niess, 2015).

Besides, the fast renewal of knowledge and technology has impacted pervasively toward teachers' learning. As a way to achieve the strategic direction toward teacher professional development, online communities of practice $(\mathrm{OCP})$ are considered a way to enhance teachers' learning process by the advanced information and technology communication ICT (Xue et al., 2021). Further, OCP can achieve success in meeting the teachers' needs. OCP has a sustained teacher professional development model with a longer period and uses a learning design that integrates ICT (Marín et al., 2018). Moreover, the online community of practice is different from the usual community of practice through the offline mode because OCP is added by the component of facilitative technology (Duncan-Howell, 2007). The added elements of technology in the OCP can sustain learning for the members as learners.

Some scholars are already concerned about designing the OCP to achieve the best way for teachers' learning by using social media platforms such as WeChat (Xue et al., 2021), Twitter (Gilbert, 2016; Wesely, 2013), and SCTNet Website (Tseng \& Kuo, 2014). The design of social media platforms-based communities provides opportunities for people to participate and learn in interaction and engagement (Gilbert, 2016). However, this study concerns another free social media platform called WhatsApp. This platform allows the users to send voice and messages without a limit. In other words, this social media platform supports the process of learning and knowledge exchange. In which those characteristics are generally fundamental aspects of the community of practice (Gilbert, 2016). This WhatsApp-based community aims to improve teachers' technology integration during the school learning transition in Indonesia from offline to online learning resulting from Covid-19. To explain the teachers' TPACK knowledge development, this study must characterize the specific learning theory. Drawn upon the social theory of learning by Wenger (1998), this study aims to see the TPACK context through learning and knowing of the teachers from the practice process and 
the extent of their TPACK level development in the OCP.

\section{Online Community of Practice as Sources of Teachers' Learning}

The school pressures teachers to learn a new skill and update their knowledge for better classroom practices. Therefore, a way for the teachers to achieve opportunities to improve their knowledge and skill is needed (Richards \& Farrell, 2005). Teacher professional development is expected to significantly enhance the teachers' quality (Adey, 2004). TPD is a teacher professional support program that focuses on systemic adjustment or changes toward the curriculum to achieve the educational environment that can stimulate teachers to keep up their passion and improve teaching quality and effectiveness (Du Plessis, 2019). It is needed for the educators as the challenges resulted from rapid changes within educational paradigms, from the curriculum changes, national tests, and the need of the students. However, in the current form, teacher professional development fails to meet the teachers' needs (Guskey, 2002).

Online community of practice (OCP) is different from the usual teacher professional development. OCP has a sustained model of TPD that has a longer period which is easily achieved by using a learning design that integrates information and technology communication (ICT) (Marín et al., 2018). As a part of a conceptual framework of a community of practice, OCP perspectives uncover learning as located in the relationship between the person and world (Wenger, 2010). The human itself acts as the social person in the social world in which the social and individual constitute each other.

Lave and Wenger (1991) define learning as a part of social practices that concerns the role of the whole person in becoming the full participant, a member, or a kind of person. Within social practices, people become different people, have meaningful relations, and respect the system of relationships. Furthermore, Hanks in Lave and Wenger (1991) claims that learning is a process in the participation framework, not in the individual's mind. In the community, the person is mediated by the different perceptions among the participants. Moreover, learning is not an act of a person; it is distributed among the participants of a community.

Various learning theories have their purposes. The differences among the theories lay on the focus of the multidimensional problem of learning and the different fundamental assumptions about knowledge, knowing, and knowers and what matters in learning (Wenger, 1998). Furthermore, Wenger's social learning theory is not the replacement for the other theories of learning. Therefore, to explore the development of TPACK of the participants in the OCP, this study uses Wenger's social learning theories specific to the practice process (practice as 
meaning) and Niess's TPACK development level theories. Three main aspects are concerned within this study are meaning, participation, and reification. The members should realize the experience meaning, the mechanical procedure like routine or procedure. The participant is defined as a social experience of living in the world in terms of social communities and active involvement in social enterprise. Then, reification refers to the concept to describe the engagement with the world as the productive meaning. Participation and reification are essential to the human experience of meaning and the nature of the practice.

\section{Technological, Pedagogical, and Content} Knowledge

TPACK is a framework that effectively supports the researcher in conceptualizing the types of knowledge that underpin the educators' technology use. The knowledge describes the educators' knowledge in using technology for teaching (Niess, 2015). TPACK framework that Mishra and Koehler developed is based upon the Shulman's framework) (Mishra \& Koehler, 2006). TPACK adapts the Pedagogical Content Knowledge (PCK) framework of Shulman $(1986,1987)$ and integrates the technology domain with PCK domains. TPACK framework consists of three kinds of knowledge: (1) knowledge related to the content of subject matter, (2) knowledge related to the pedagogy, and knowledge related to technology to avoid detachment between each domain and to address the issues within technological, pedagogical, and content knowledge, TPACK framework as a conceptual framework is expected to be capable in "connecting, interacting, affordance, and constraining" among technological, pedagogical, and content knowledge domain (Mishra \& Koehler, 2006).

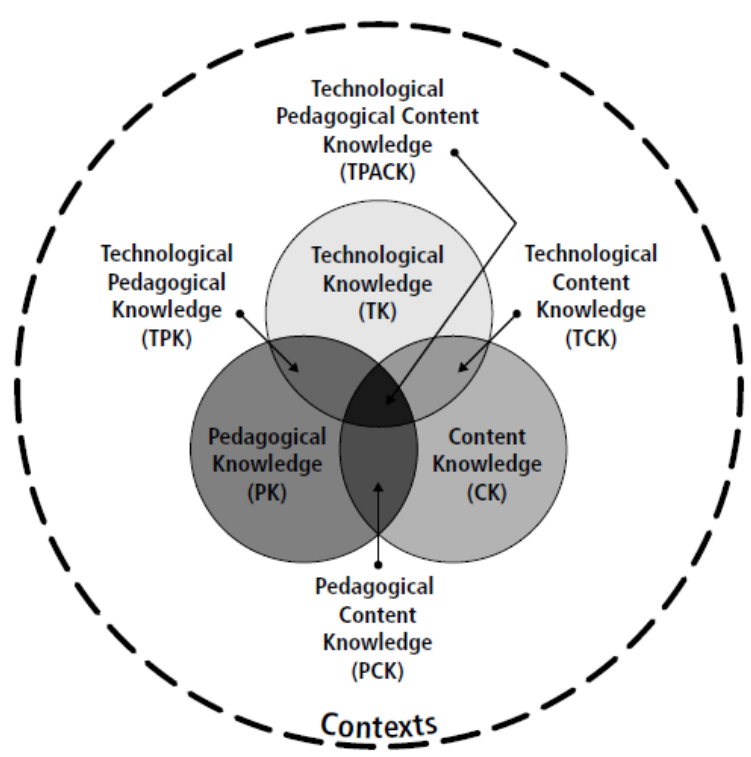

Picture 1. The TPACK framework and each knowledge domain (Koehler et al., 2013)

TPACK is defined as a developing form of knowledge developed by the synthesis of teachers' technological knowledge (TK), pedagogical knowledge (PK), and content knowledge (CK). It is as well as intersecting knowledge, pedagogical content knowledge (PCK), technological content knowledge (TCK), and technological pedagogical knowledge (TPK) that are constructed by the interconnection of TK, PK, and CK (Mishra \& Koehler, 2006). Teachers 
depend on this framework when designing and implementing curriculum and instruction while guiding the learners' thinking and learning with digital technology in the specific content area (Niess, 2015).

Thus, there are five levels to describe the development process of TPACK of the teachers. As stated by Niess (2015), the classified five TPACK levels are: (1) recognizing where teachers are able to use technology and recognize an alignment of the technology capabilities with the content knowledge; (2) accepting where teachers form a favourable, or unfavourable, attitude toward teaching and learning of specific topics of subject matter; (3) adapting where teachers engage in and implement in their classroom activities that lead to a choice to adopt, or reject, teaching and learning topics of subject matter with technology; (4) exploring where teachers integrate technology as learning tools, when teaching and learning of multiple topic of subject matter, and where they consistently explore opportunities to use technology as learning tools in additional topics; and (5) advancing where teachers evaluate students' understanding using technology as learning tools and where they actively support the decision to integrate teaching and learning the topic of subject matter with technology.

Few studies have measured TPACK knowledge development and the relation to teachers' professional development using a survey (Drajati et al., 2018) and a mixed-methods self-report survey (Koh \& Chai, 2018). However, the nature of TPACK focus on its context needs to be investigated deeply to gain a better understanding. Especially in what ways the TPACK is enacted within the complex practice like the community of practice. Mishra and Koehler (2006) declare that context can influence teachers' TPACK knowledge. They argue that no single technological solution applies to every teacher in every course and view of teaching. Therefore, teaching involves developing an understanding of the complex relationship of technology, content, and pedagogy. Moreover, by using this complex understanding, it can develop the appropriate context specificstrategies and representations.

Rosenberg and Koehler (2015) state the distribution of studies that address TPACK and the relation with context is only 36 per cent. Therefore, further studies with greater attention on the context concerning TPACK are necessary. By far in Indonesia, the most recent TPACK based research Drajati et al. (2018) (survey) and Koh and Chai (2018)(selfreport survey) is only concerned with investigating the TPACK development of teachers regardless of its context. Drajati et al.'s study only concern teachers' TPACK enactment on the perception and implementation of TPACK knowledge. Meanwhile, Koh and Chai (2018) investigate the teachers' TPACK-21CL development, multi-prong pedagogical reasoning activities that can support TPD, 
and their learning outcomes for a two-day TPD workshop. Therefore, the selfassessment survey can explain why the context is often ignored or unclear in the TPACK research (Pareto \& Willermark, 2019). Therefore, in this study, by exploring the context in which the participants participate in the OCP, participants' TPACK knowledge development will be easily understood. The exploration of the context uses the CoP notion of practice to explain how context can influence the development of TPACK.

\section{METHOD}

\section{Participants}

The WhatsApp-based community (OCP) was established during the pandemic COVID 19 in the year 2020. This platform supported the process of learning and knowledge exchange between members. There were hundreds of members who participated in the OCP from different domains and teaching levels. The aims of the community for teachers and lecturers are: (1) assisting them related to the use of media of technology for classroom practices, (2) helping them in creating and developing learning materials using technology, and (3) giving an understanding related to how effectively evaluate the teaching-learning process with using technology.

The participants of this study were selected purposively based on several criteria. There were two out of one hundred in-service teachers as the participants of this study. The strategy to recruit the participants was by posting a broadcast on the OCP, calling for expression of interest. The invitation followed human research ethics protocols. The protocols indicated that the participation of the participants was voluntary, and they were free to withdraw at any stage without prejudice. After the teachers were willing to participate in the research, they were selected based on their activeness (visibility during the scheduled activities). The visibility was characterized by the number of times they had a chat with members or mentors during the scheduled activities in the WhatsApp group. Table 3 shows the summary of demographic information obtained from the participants.

Table 1. Demographic Data of Participants

\begin{tabular}{lllll}
\hline $\begin{array}{l}\text { Name } \\
\text { Pseud } \\
\text { onyms }\end{array}$ & Gender & Age & $\begin{array}{l}\text { Teaching } \\
\text { Experiences }\end{array}$ & $\begin{array}{l}\text { Curriculum } \\
\text { focus }\end{array}$ \\
\hline Rahmi & Female & $31-40$ & $\begin{array}{l}\text { More than 5 } \\
\text { years }\end{array}$ & $\begin{array}{l}\text { English } \\
\text { language } \\
\text { subject }\end{array}$ \\
& & years & More than $\begin{array}{l}\text { English } \\
\text { language } \\
\text { subject }\end{array}$ \\
\hline
\end{tabular}

\section{Data Collection}

In this study, there were two points of data collection. The first was a WhatsApp-chat transcript. The conversations in WhatsApp between the members and mentors were not in logical order. Therefore, in this study, the talks were classified into specific themes. The second was a Semi-structured interview 
adapted from Wenger' (1998) and Niess' (2015) theories. The semi-structured interview was conducted to gain better data of the participants' perspectives related to the research topic.

\section{Data Analysis}

This study followed the Yin (2016) model in analyzing the qualitative data. There are five phases to analyze the data: compiling, disassembling, reassembling, interpreting, and concluding. First, in the phase of collecting, the WhatsApp chat and interview transcript was compiled and sorted. In this step, the researchers read and re-read the data to be familiarised with it. Second, in the phase of disassembling, the compiled data was broken into smaller fragments or by using two-level code. Third, in the stage of reassembling, the data were grouped into the same concept or group to find its relation. Fourth, in the interpreting step, the reassembled material was created into a narrative. This step was considered as the step where the researchers gave the meaning of the reassembled data. Last, the conclusion of this study was elaborated based on the phase of interpreting.

\section{RESULTS AND DISCUSSION}

Every practice is in some form of knowledge and knowing participating in that practice (Wenger, 1998). All of the OCP's members participated in the training (activities) that existed in the OCP. The following table is summarised practices in the OCP. The main mentor explained several technological tools and pedagogical understanding for teaching via Youtube. However, all of the discussions between the members and mentor were conducted at the WhatsApp group chat.

\section{Table 2. Summarised Activities in the OCP}

\begin{tabular}{|c|c|c|}
\hline Duration & Activities & Description \\
\hline 1 week & $\begin{array}{l}\text { - General } \\
\text { introduction related } \\
\text { to } \\
\text { - StreamYard by the } \\
\text { head of StreamYard. } \\
\text { Get started to use } \\
\text { StreamYard (how } \\
\text { to: make the } \\
\text { account, make a } \\
\text { scheduled meeting, } \\
\text { and connect the } \\
\text { StreamYard to } \\
\text { Youtube, Facebook, } \\
\text { and any other social } \\
\text { media platforms). } \\
\text { Operate the } \\
\text { StreamYard (using } \\
\text { the features). } \\
\text { - Introduction of } \\
\text { TPACK as a } \\
\text { framework to } \\
\text { design classroom } \\
\text { practices. ant and } \\
\text { - PowerPoint (general } \\
\text { Ispring the } \\
\text { introduction, how to } \\
\text { get started, the } \\
\text { features, and } \\
\text { convert Powerpoint } \\
\text { and Ispring } \\
\text { question into the } \\
\text { application for } \\
\text { using APK builder). } \\
\text { - General } \\
\text { Introduction related } \\
\text { to Microsoft Teams, } \\
\text { how to get started, } \\
\text { and the feature. }\end{array}$ & 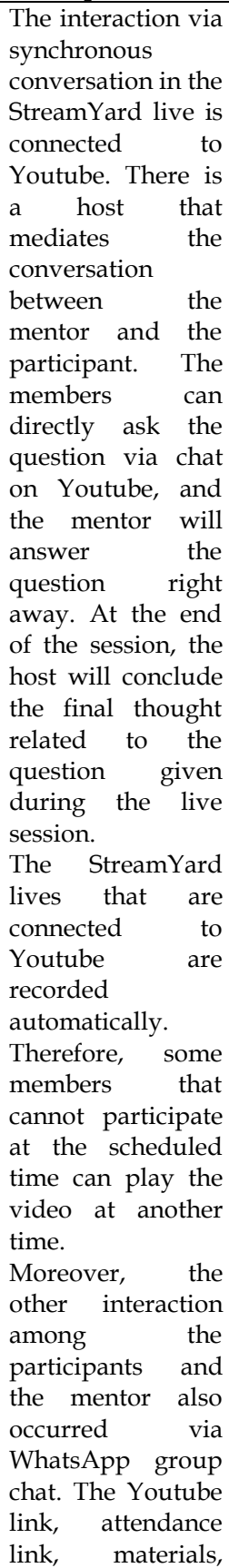 \\
\hline
\end{tabular}




\begin{tabular}{|c|c|c|}
\hline & & $\begin{array}{l}\text { and any other } \\
\text { information about } \\
\text { the workshop are } \\
\text { shared via the } \\
\text { WhatsApp group. }\end{array}$ \\
\hline 2 weeks & 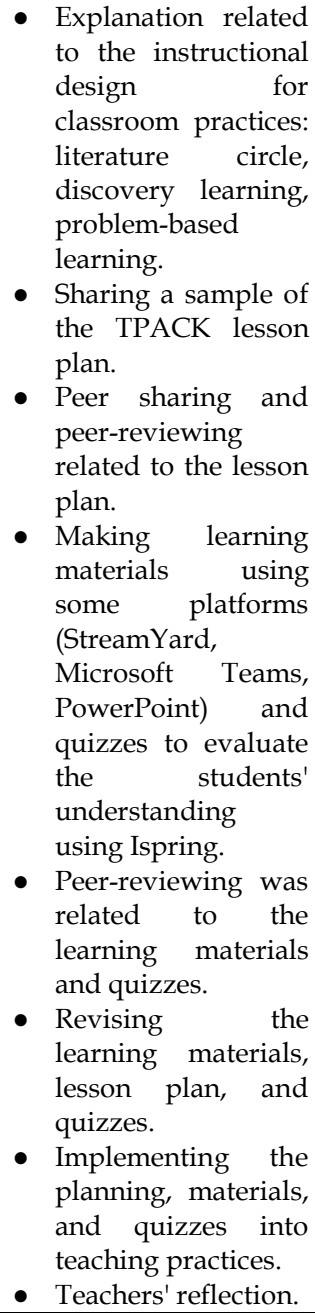 & $\begin{array}{l}\text { Every day for } \\
\text { three weeks, } \\
\text { mentors will open } \\
\text { the discussion } \\
\text { with the general } \\
\text { information } \\
\text { related to the topic } \\
\text { that will be } \\
\text { discussed. The } \\
\text { mentors also } \\
\text { explain the } \\
\text { important points } \\
\text { of the related } \\
\text { topics. Then, the } \\
\text { mentor will open a } \\
\text { discussion session. } \\
\text { This interaction } \\
\text { among the } \\
\text { participants and } \\
\text { mentors occurred } \\
\text { via WhatsApp } \\
\text { group text chat. }\end{array}$ \\
\hline
\end{tabular}

\section{Rahmi's experiences}

To experience meaning in the OCP, the members should realize some routines (Wenger, 1998). In the OCP, both participants experienced various practices and activities that involved their negotiation of meaning. Rahmi felt that "participating in the activities in OCOP improved her TPACK level development, specifically in the level of adapting". In level adapting, Rahmi thinks that "she can engage in and implement the ideas from the workshop for their classroom activities". The level of adapting is where the teachers implement teaching with integrating technology (Niess, 2015). However, from Rahmi's statement, she used the Microsoft teams only two times for her class. She faced some obstacles. In line with Phillips (2016), the wicked problem regarding technology still becomes the main issue in teaching. In Rahmi's class, some students had technological barriers such as low access to the internet and did not have technological tools like phones, laptops, or PCs. Among 30 students in a class, only five students were ready to take part in the Microsoft Teams class. To face the issue of technological barriers, Rahmi considered rejecting the technology or replacing it with other technology. Moreover, Rahmi stated:

"there were several routines experienced by her that made her adopt technological tools for her classroom practices, such as workshops of technological application like Microsoft Teams, Streamyard, and Ispring and discussion between the members related to the problems during the online classroom".

The workshop concerned the Mentors' explanation, but also the members had a task to use all of the applications for their classroom practices. All of the members were obligated to submit several tasks. The following table 3 is the list of the tasks. 
Table 3. The List of Members' Task

\begin{tabular}{ll} 
a. The lesson plan integrates the technological \\
application. \\
\hline b. $\begin{array}{l}\text { Making a live stream of teaching by using } \\
\text { Streamyard that is connected to social media (ex: } \\
\text { Youtube, Facebook, etc.). }\end{array}$ \\
\hline c. Making a quiz using Ispring. \\
\hline d. $\begin{array}{l}\text { Have a class meeting with their students by using } \\
\text { Microsoft teams, add an assignment on Teams for } \\
\text { students, and record the meeting. }\end{array}$
\end{tabular}

Rahmi's stated that although there were a lot of ideas and technological tools explained in the OCP, she needed to select the best ideas or technological devices that were suitable for her classroom condition. Not all the ideas from the OCP were appropriate to be implemented in her school.

Rahmi acknowledged that her participation in the OCP was not quite intensive. She mostly took part in the discussion while there was an interesting topic. It could be seen from her appearance in the following themes (see table 4). Rahmi mostly makes a starting point of a discussion. There was an exchange of information between the members of Rahmi regarding the issue that was discussed.

Table 4. Theme of Discussion

\begin{tabular}{llll}
\hline $\begin{array}{l}\text { Name } \\
\text { Pseudonyms }\end{array}$ & First week & $\begin{array}{l}\text { Second } \\
\text { week }\end{array}$ & Third week \\
\hline Rahmi & $\begin{array}{l}\text { Asking } \\
\text { about the } \\
\text { link of I } \\
\text { spring Apps the task }\end{array}$ & $\begin{array}{l}\text { Asking } \\
\text { about how } \\
\text { to submit }\end{array}$ & $\begin{array}{l}\text { Answering } \\
\text { other } \\
\text { members } \\
\text { question } \\
\text { about the } \\
\text { due date for } \\
\text { the task }\end{array}$ \\
& $\begin{array}{l}\text { Asking } \\
\text { about the } \\
\text { link of } \\
\text { absent list }\end{array}$ & \\
\hline
\end{tabular}

Tyarakanita, A., Nurkamto, J., \& Drajati, N.| The Indonesian EFL Teachers' TPACK Development..., 121-134 
students. However, not all the materials that the mentors explained could be implemented in his classroom. He thought that there was a slight improvement regarding his classroom materials. The following is Umar's statement.

"My student feels there was an improvement in my classroom practice after I participated in this OCP. The reason was that I mostly asked the student to do the task by distributing a paper-based task. Now I used Ispring to make a quiz automatically attached to my PowerPoint. After they learned the materials, they could do the task and automatically get the score."

Umar already implemented technology for evaluating his students; he felt that his participation in the OCP developed his TPACK on the level of recognizing. Umar used technology before he participated in the OCP. After participating in the $\mathrm{OCP}$, he felt that he recognized an alignment of the technology capabilities with the content knowledge. The reason was that, during the discussion with the other member, a member asked Umar about how to install Ispring. When Umar explained step by step by WhatsApp chat, other members seemed so lost with his explanation. Then Umar made a stepby-step video to explain it. After this activity, he realized that technology and content knowledge had an essential role in making the target learners easily understand the materials.

\section{CONCLUSION}

The results of this study show that in TPACK level development, each of the teachers was experiencing different levels of development: Umar was at the level of accepting while Rahmi was at the level of adapting. Although the activities on OCP did not support the teachers in achieving the full TPACK level development: recognizing, accepting, adapting, exploring, and advancing, the TPACK of teachers was a bit developed after they participated in the OCP. As a result, the primary findings of this present study are that (1) teachers' participation in discussion and all OCP activities enhance instructors. TPACK growth depends on teachers applying the meanings of the OCP to their lives, and (2) reification of teachers takes the form of exchanging experiences and solutions with other members on problematic issues in classroom practices. However, during the process of learning in the OCP, the TPACK development seems not significant. Therefore, it is necessary to carefully design teacher professional programs that can improve the teachers' knowledge. OCP needs to be concerned about making the teachers actively engaged in discussion and making the process of learning more meaningful for the teachers.

This current study's limitation is that the chat transcript data is not analyzed deeply by using a specific framework. Therefore, the suggestion for future research is to continue this study using 
another approach like a chat analysis approach to deeply understand the contextual process of TPACK development in the community through the chat interaction between the members.

\section{ACKNOWLEDGEMENT}

Thank you for all participants' contributions to this current study.

\section{AUTHOR CONTRIBUTION STATEMENT}

In the process of writing this manuscript, AT is assisted by NAD and JN. NAD and JN were the thesis consultants of AT. NAD and JN provided valuable feedback regarding the manuscripts.

\section{REFERENCES}

Adey, P. (2004). The Professional Development of Teachers: Practice and Theory. Kluwer Academic Publishers. https://doi.org/10.1007/0-30648518-4

Caena, F., \& Redecker, C. (2019). Aligning teacher competence frameworks to 21st century challenges: The case for the European Digital Competence Framework for Educators (Digcompedu). European Journal of Education, 54(3), 356-369. https://doi.org/10.1111/ejed.12345

Drajati, N. A., Tan, L., Haryati, S., Rochsantiningsih, D., \& Zainnuri, H. (2018). Investigating English Language Teachers in Developing TPACK and Multimodal Literacy.
Indonesian Journal of Applied Linguistics, $\quad 7(3), \quad 575$. https://doi.org/10.17509/ijal.v7i3.9 806

Du Plessis, A. E. (2019). Professional Support Beyond Initial Teacher Education: Pedagogical Discernment and the Influence of Out-of-Field Teaching Practices. Springer Singapore.

https://doi.org/10.1007/978-981-139722-6

Duncan-Howell, J. (2007). Online Communities of Practice and their Role in the Professional Development of Teachers. (Doctoral dissertation, Queensland University of Technology).

Gilbert, S. (2016). Learning in a Twitterbased community of practice: An exploration of knowledge exchange as a motivation for participation in \#hcsmca. Information, Communication $\mathcal{E} \quad$ Society, 19(9), 1214-1232. https://doi.org/10.1080/1369118X.2 016.1186715

Guskey, T. R. (2002). Professional Development and Teacher Change. Teachers and Teaching, 8(3), 381-391. https://doi.org/10.1080/1354060021 00000512

Koehler, M. J., Mishra, P., Kereluik, K., Shin, T. S., \& Graham, C. R. (2014). The Technological Pedagogical Content Knowledge Framework. In J. M. Spector, M. D. Merrill, J. Elen, \& M. J. Bishop (Eds.), Handbook of Research on Educational Communications and Technology (pp. 101-111). Springer New York. 
https://doi.org/10.1007/978-1-46143185-5_9

Koh, J. H. L., \& Chai, C. S. (2018). Developing Indonesia teachers' technological pedagogical content knowledge for 21st century learning (TPACK-21CL) through a multi-prong approach. 24.

Lave, J., \& Wenger, E. (1991). Situated Learning: Legitimate peripheral participation. Cambridge University Press.

Marín, V. I., Asensio-Pérez, J. I., VillagráSobrino, S., Hernández-Leo, D., \& García-Sastre, S. (2018). Supporting online collaborative design for teacher professional development. Technology, Pedagogy and Education, 27(5), $571-587$ https://doi.org/10.1080/1475939X.2 018.1547787

Mishra, P., \& Koehler, M. J. (2006). Technological Pedagogical Content Knowledge: A Framework for Teacher Knowledge. Teachers College Record, 108(6), 1017-1054. https://doi.org/10.1111/j.14679620.2006.00684.x

Niess M.L. (2015) Transforming Teachers' Knowledge: Learning Trajectories for Advancing Teacher Education for Teaching with Technology. In Angeli, C., \& Valanides, N. (Eds.). (2015). Technological Pedagogical Content Knowledge. Springer US. https:// doi.org/10.1007/978-1-48998080-9

Pareto, L., \& Willermark, S. (2019). TPACK In Situ: A Design-Based Approach
Supporting Professional Development in Practice. Journal of Educational Computing Research, 57(5), 1186-1226.

https://doi.org/10.1177/0735633118 783180

Phillips, M. (2016). Digital Technology, Schools and Teachers' Workplace Learning. Palgrave Macmillan UK. https://doi.org/10.1057/978-1-13752462-1

Phillips, M. (2017). Processes of practice and identity shaping teachers' TPACK enactment in a community of practice. Education and Information Technologies, 22(4), 1771-1796. https://doi.org/10.1007/s10639-0169512-y

Richards, J. C., \& Farrell, T. S. C. (2005). Professional development for language teachers strategies for teacher learning. Cambridge University Press.

Rosenberg, J. M., \& Koehler, M. J. (2015). Context and Technological Pedagogical Content Knowledge (TPACK): A Systematic Review. Journal of Research on Technology in Education, 47(3), 186-210. https://doi.org/10.1080/15391523.2 015.1052663

Shulman, L. (1987). Knowledge and Teaching:Foundations of the New Reform. Harvard Educational Review, 57(1), 1-23. https://doi.org/10.17763/haer.57.1.j 463w79r56455411

Shulman, L. S. (1986). Those Who Understand: Knowledge Growth in Teaching. 11. 
Tseng, F.-C., \& Kuo, F.-Y. (2014). A study of social participation and knowledge sharing in the teachers' online professional community of practice. Computers \& Education, 72, 37-47. https://doi.org/10.1016/j.compedu. 2013.10.005

Wenger, E. (1998). Communities of practice: Learning, meaning, and identity. Cambridge University Press.

Wesely, P. M. (2013). Investigating the Community of Practice of World Language Educators on Twitter. Journal of Teacher Education, 64(4), 305-318.

https://doi.org/10.1177/0022487113 489032

Xue, S., Hu, X., Chi, X., \& Zhang, J. (2021). Building an online community of practice through WeChat for teacher professional learning. Professional Development in Education, 47(4), 613637.

https://doi.org/10.1080/19415257.20 19.1647273

Yin, R. K. (2016). Qualitative research from start to finish (Second edition). The Guilford Press. 
Pedagogy: Journal of English Language Teaching, (9)2: 121-134 